\title{
Wind Power Renewable Energy Generation To Reduce Cost And The Greenhouse Effect
}

\author{
Hamilton Pozo \\ CEETEPS/Fatec Rubens Lara. Brazil \\ Washington Luiz Pereira Soares \\ Universidade Santa Cecilia. Brazil \\ Getulio Kazue Akabane \\ Centro Estadual de Educação Tecnológica. Brazil
}

\begin{abstract}
The objective of this research is to analyze and provide economic bases for the use of wind energy, replacing the thermals plants in process of cost reduction, their positive impact on the economy and the environment. The energy obtained through the force of the winds is one of the oldest of the energies known and used by man. This conception of energy production was again evaluated and tested more objectively after the 1980s, especially in the USA and Europe with strong support from ERDA-Energy Research and Development Administration in the development of special turbines to capture energy from the winds and make it economically viable and sustainable. Experiments show that the use of wind energy as an economically and ecologically correct alternative for use in small and large power plants and reduce climate change.)
\end{abstract}

Keywords: renewable energy, sustainable, $\mathrm{CO}^{2}$ emission reduction, climate change

\section{INTRODUCTION}

Energy produced by the action of the wind started to have a greater development at the end of the 70s but specially during the 80 s by some big companies from the USA and Europe that were creating projects of use of wind power with business objectives and economic purposes. The main companies were Boeing, General Electric, Enercon WindPower, Grumman, Kaman, Zephyr Wind Dynamo and others.

Since the first oil crisis in the 1970s and in the following decades, the world has suffered and experienced many energy crises, especially non-renewable ones, causing great concern over its costs and its promotion of climate change regarding the indiscriminate use of oil. Developments for renewable, economic and ecological energy sources that do not attack and do not damage the ecosystem have been made. However, wind power faces problems with the inconstancy of the quantity and speed of the existing winds. The generators systems in the production of energy align to the problem involved with the need to use a process of storage for the generated energy for better and efficient use of this system. The studies of Mason, Page; Williamson, (2010) show that the growth of electric power generation with renewable sources is the key to the necessary decrease of emissions of greenhouse gases in the atmosphere. According to the British Petroleum Energy Outlook report (2016), renewable energy sources are expected to grow rapidly, quadrupling their world share by 2035.

Energy consumption per capita in Brazil is still incipient and, therefore, energy efficiency measures do not have as much government support. According to Dutra \& Guedes (2013), it is still possible to progress in a sustainable way without reducing energy consumption, taking 
advantage of the available renewable energies, such as wind power. These aspects are important when working towards sustainable development, projecting on energy efficiency, a more effective way of simultaneously reducing local and global environmental costs and impacts. However, satisfactory results can already be verified in several countries and even here, in Brazil, especially in the Northeast and North of Paraná.

The system is overcoming the economic barrier, which is still the major obstacle to this project. It has the great advantage of not needing fossil fuels, nor degrading air and water quality since the amount of noise is very low nor causing scarce or almost no damage to human, animal or plant life and to the ecosystem. The north and northeast coast of Brazil have already emerged as points of strong attractiveness for the commercial deployment of this power generation system. As of 2009, the wind source has definitely entered the Brazilian power matrix and the world industry map with wind power being negotiated at increasing auctions and at very competitive prices.

According to Aneel (2017), in 2016 the second alternative source of energy in Brazil with new capacity installed was wind energy, with 2,564 MW, representing an increase of more than $20 \%$ compared to 2015 . By the end of 2016 , the capacity of the wind farms in operation was 10,092 MW. The state of Rio Grande do Norte had the largest installed wind energy generation in the country, with $920 \mathrm{MW}$, followed by the state of Ceará, which contributed about $600 \mathrm{MW}$, and the state of Bahia, with 520 MW inserted (Eletrobras (2014); Maia \& Andrade, 2017).

The objective of this work is to compare the emission of GHG (in t equivalent to $\mathrm{CO}^{2}$ ) per unit of electric energy (MWh) for the different cycles, calculating the emission/electricity coefficient, being the emission in electric generation in the cycle of fuel used.

\section{THEORICAL FRAMEWORK}

There is great concern about the risks of the greenhouse effect and its intensification and effects on the planet's climate. The assessed changes in the greenhouse effect are causing global climate change, which gives an idea of the difficulty in developing models that predict its consequences. Climate is an abstract and complex concept that involves data of temperature, humidity, types and amount of precipitation, direction and wind speed, atmospheric pressure, solar radiation, type of clouds and the area they cover, as well as other phenomena of the time fog, storms, frosts and the relationships between them (Britannica, 2001).

Research indicates that climate change in the 20th century has had a number of impacts on biodiversity as reported by McCarty (2001) and Walther et al. (2005). The effects occurred are associated to changes in the distribution and risk of extinction of species according to Franco et al. (2006), Parmesan (2006) and Foden et al. (2007).

In the atmosphere, thermal energy exchange processes are important for the Earth's climate. There is the conduction of heat, the convection and the interaction of electromagnetic radiation with the gases and particles that make up the atmosphere. Atmospheric gases that retain little solar radiation while absorbing more efficiently the radiation emitted by the Earth's surface are called greenhouse gases. The most critical gases that occur due to natural, industrial and social processes are, among others, water vapor, carbon dioxide, ozone, methane and nitrous oxide.

Climate change is understood today as a result of the increased concentration of greenhouse gases in the atmosphere, especially carbon dioxide $\left(\mathrm{CO}^{2}\right)$ and methane gas $(\mathrm{CH} 4)$, causing 
global warming and its consequences. The increased concentration of these gases in the atmosphere is attributed to anthropogenic actions, including deforestation and burning of fossil fuels such as oil, coal and natural gas. Before the Industrial Revolution in the 18th century, atmospheric carbon levels on average were at $280 \mathrm{ppm}$ (parts per million). Currently, this concentration is around $379 \mathrm{ppm}$, which entails an increase of 35\%. However, the great threat to the future of this planet's biodiversity lies in accelerated climate change, which is accompanied by changes in landscapes, derived from disorganized land use according to Mea (2005) and Lovejoy \& Hannah (2005).

In 1992, the problem was given a new status within the world political agenda, with the creation of the Climate Convention during the United Nations Conference on Environment and Development held in Rio de Janeiro, known as Rio-92. The Climate Convention's main objective is to stabilize concentrations of greenhouse gases in the atmosphere at a level that would prevent dangerous anthropogenic interference with the climate system. The Kyoto Protocol, which defines market mechanisms unprecedented in the international arena, proposes the responsibilities and obligations of the actors involved, thus opening up the opportunities for sustainable economic and social development (MCT, 2008).

The Intergovernmental Panel on Climate Change (IPCC) report (2007), using more accurate information bases and computational climate modeling methodologies, significantly reduced uncertainties about the actual occurrence of climate change. In 2007, the 2,500 IPCC scientists released the panel's fourth assessment report, which has become one of the most cited works worldwide in climate change discussions.

This deviates substantially from the Intergovernmental Panel on Climate Change's (IPCC) Renewable Energy Sources evaluation that says emissions from turbines are 8 to $20 \mathrm{~g} \mathrm{CO}_{2} / \mathrm{kWh}$ [16]. Less than half of the turbines analysed fell within the IPCC's range (Kabir, et al. 2012). They classify as unequivocal the responsibility of man on climate change and point to an average global temperature increase of around 3 degrees Celsius by 2100. In Brazil, climate models indicate that warming of $4^{\circ} \mathrm{C}$ to $6^{\circ} \mathrm{C}$ may occur in some parts of the country, including the Amazon, by the end of this century.

Another element that affects climate change is the disposal of solid waste that occurs in Brazil and other developing countries. This factor needs a lot of attention because it represents the biggest deficit and environmental problem. A study of NAE (2005) shows that more than 35\% of the waste collected is sent to landfills. The disposal of this waste contributes to the increase of the greenhouse effect, either in landfills or open dumps, as they are decomposed in the bio digestion process that transforms the material deposited therein into liquids and gases, in particular $\mathrm{CO}^{2}$ and $\mathrm{CH} 4$, a mixture known as biogas (Monzoni, 2009).

Generally, direct and indirect GHG emissions are required throughout the entire energy and fuel production chain to be compared with those of other energy cycles using coherent procedures. However, in this study it was considered to subject the analysis of power generation.

The main greenhouse gases, after water vapor, are carbon dioxide $\mathrm{CO}^{2}$, methane gas $\mathrm{CH} 4$ and nitrous oxide N20. It should be noted that these three gases derive from both natural and human sources, and human action has played an important role in increasing their atmospheric concentration. Of the three gases, carbon dioxide has the highest potential for greenhouse effect. This gas is released into the environment in more significant quantities than the others, and its radiative bearing takes centuries to begin to decline. The radiative forcing of 
a gas is its ability to cause changes in the climate according to IPCC (2007a, p.2). Then, the gas that contributes most to the greenhouse effect is methane and its radiative power is 21 times greater than that of carbon dioxide, but it decreases faster than the previous one and it is released into the atmosphere in much smaller quantities than carbon dioxide. Thirdly, the radiative power of nitrous oxide is more than 300 times greater than that of $\mathrm{CO}^{2}$ and remains high for centuries, but its emission is in much lower quantities.

Energy-generating systems from hydroelectric plants and thermal plants emit methane, a greenhouse gas with 25 times more impact on global warming per ton of gas than carbon dioxide, according to the latest report of the Intergovernmental Panel of Climate Change (IPCC) (Forster et al., 2007). More recent studies, which include indirect effects not included in the IPCC value, indicate a 34 -fold impact of $\mathrm{CO}^{2}$, considering the same 100-year time scale (Shindell et al., 2009).

\section{The wind energy generation system}

Currently, data on climate issues have changed. Positively, unlike 25 years ago -when the climate issue first emerged - and even unlike seven years ago, soon after the collapse of the last ClimSummit in Copenhagen during 2009, for many, if not most people, the climatic issue brought hope for serious action by the governments to make necessary investments. Nowadays, there is technology to solve the problem and to do so economically. In accordance to the words of Edenhofer (2011) in IPCC Working Group III, revealing the group's latest work on climate change mitigation: "it will not cost governments much to save the planet".

Wind and solar systems are taking on the energy sector and becoming a viable and fundamental alternative to the sustainability of the planet. Electrical mobility and technology development, advancement of materials science, equipment and energy efficiency practices, and an almost inexhaustible list of other technologies and innovation, provide the tools needed to review the problems that contribute to the critical factors of climate change. One of the strongest challenges is regarding the emission of $\mathrm{CO}^{2}$ that affects the climatic conditions of our planet. Wind energy is the kinetic energy contained in the moving air masses (wind). Its utilization occurs through the conversion of the kinetic energy of translation into kinetic energy of rotation, with the use of wind turbines, also denominated aero-generators, for the generation of electricity.

Currently, the energy matrix is responsible for the majority of greenhouse gas emissions, giving priority to the use of clean energy such as solar, biomass and wind energy. Wind turbines are used for the conversion of wind to electric power, which are the aero-generators (Alves, 2010). Brazil has a high potential for renewable energy sources, wind energy plants being one of the most important (Ribeiro et al., 2012). The wind energy is obtained through the use of the kinetic energy of the winds, resulting from the moving air masses. Recent research and new technological developments in transmission systems, proper aerodynamics, and controls and operation of the turbines have reduced costs and improved system performance and reliability. The cost of a project and equipment was one of the main obstacles to the commercial use of wind energy and in the last ten years its costs have reduced significantly.

Thomson \& Harrison (2014) identified that system lifetime and the methodology used for allocating recycling credits were also significant. It is important to note, however, that capacity factor and system lifetime are a function of the specific design and location of each wind farm and are therefore likely to vary between farms. In arriving at their harmonized values (Dolan 
and Heath, 2012) found the mean assumed capacity factor of existing studies to be $30 \%$ onshore and 40\% offshore, which are slightly higher than the respective values for.

As of 2009, the wind source has definitely entered the Brazilian power matrix and the world industry map with wind energy being negotiated at increasing auctions and at very competitive prices. The premiere at auctions took place at the Reserve Energy Auction, held on December 12th, 2009. In this event, dedicated exclusively to the wind energy source, 1,805.7 MW of 71 projects were contracted at an average price of US \$42.40/MWh (discount of $21.49 \%$ compared to the ceiling price of US $\$ 19.27 / \mathrm{MWh}$ ). The investments involved in the construction of these parks totaled approximately US \$2,17 billion (2009 prices) and were distributed in five states in the northeastern and southern regions: Rio Grande do Norte, Ceará, Bahia, Sergipe and Rio Grande do Sul. There was a boost and, from then on, the wind source inaugurated a competitive phase with increasing volumes and prices falling systematically in the following auctions. Brazil started to present the lowest price per MWh of wind energy in the world (ABEEOLICA, 2014).

After 2009, government investments and actions led Brazil to position itself in the 13th place among all countries with wind farms in 2013, and it can expect to occupy the 10th position in 2018. The volume contracted between 2009 and 2014 is very expressive, and a total of 15.2 GW should be installed. This would allow an extraordinary jump in the participation of the wind energy source in the Brazilian electricity matrix; from $1.8 \%$ in 2013 to $10.4 \%$ in 2018. This figure will be higher than the $6.9 \%$ biomass and very close to the $14.5 \%$ thermal (EWFBrazil, 2015).

Looking only at the recent period (2014), one can see Brazil's position regarding the installation of wind energy plants worldwide, ranking third-largest wind energy contractor, behind only China and Germany and ahead of USA and other European countries, as can be seen below in Table 2 .

Below, Table 1 shows the situation of Brazil in the world ranking.

Table 1 - Installed global wind capacity 2013 (GW)

\begin{tabular}{|c|c|c|c|c|c|c|}
\hline Pos. & Country & GW & & Pos. & Country & GW \\
\hline 1 & China & 91,4 & & 11 & Portugal & 4,72 \\
\hline 2 & USA & 61,0 & & 12 & Sweden & 4,47 \\
\hline 3 & Germany & 34,2 & & $\mathbf{1 3}$ & Brazil & $\mathbf{3 , 4 6}$ \\
\hline 4 & Spain & 22,9 & & 14 & Poland & 3,39 \\
\hline 5 & India & 20,1 & 15 & Australia & 3,24 \\
\hline 6 & United & 10,5 & 16 & Turkey & 2,96 \\
\hline 7 & Italy & 8,55 & 17 & Netherlan & 2,69 \\
\hline 8 & France & 8,25 & 18 & Japan & 2,66 \\
\hline 9 & Canada & 7,80 & 19 & Romania & 2,60 \\
\hline 10 & Denmark & 4,77 & & 20 & Ireland & 2,04 \\
\hline
\end{tabular}

Source: Global Wind Energy Council, 2015.

In the recent period (2014), one can see Brazil's position regarding the installation of wind energy plants worldwide, ranking third-largest wind energy contractor, behind only China and Germany and ahead of USA and other European countries, as can be seen below in Table 2 . 
Table 2 - Addition of installed capacity in wind energy, 1st-Sem / 2014

\begin{tabular}{|c|c|c|c|c|c|}
\hline POS. & Country & GW & POS & Country & GW \\
\hline 1 & China & 7,22 & 6 & Canada & 0,70 \\
\hline 2 & Germany & 1,76 & 7 & United Kingdon & 0,70 \\
\hline $\mathbf{3}$ & Brazil & $\mathbf{1 , 2}$ & 8 & Australia & 0,70 \\
\hline 4 & India & 1,06 & 9 & Turkey & 0,53 \\
\hline 5 & USA & 0,88 & 10 & France & 0,53 \\
\hline \multicolumn{7}{|c}{ Source: GWEC, (2015) }
\end{tabular}

For wind energy to be considered technically usable, its density must be greater than or equal to $500 \mathrm{~W} / \mathrm{m} 2$ at a height of $50 \mathrm{~m}$, which requires a minimum wind speed of 7 to $8 \mathrm{~m} / \mathrm{s}$ (Grubb \& Meyer, 1993). The evaluation of wind potential in a region requires systematic data collection and analysis on wind speed and regime (Silva, 2013). Generally, a rigorous assessment requires specific surveys, but data collected at airports, meteorological stations and other similar applications can provide an initial estimate of the gross or theoretical wind energy potential.

The system is overcoming the economic barrier, which is still the major obstacle to this project. Nevertheless, it has great advantages like not needing fossil fuels, not degrading air and water quality, and the facts that the amount of noise is very low and that it causes scarce or almost no damage to human life or animal and plant life. Also, all along the north and northeast coast of Brazil it has already emerged as points of strong attractiveness for the commercial deployment of this power generation system.

An important element for wind power is the classification of wind speed in each topographic region of the country. In Table 3 below, the average annual velocities of winds at $50 \mathrm{~m}$ height in $\mathrm{m} / \mathrm{s}(\mathrm{Vm})$ and the mean energy density in $\mathrm{W} / \mathrm{m}^{2}(\mathrm{MS})$ are shown. These values were obtained in the following standard conditions: altitude at sea level; temperature of $20^{\circ} \mathrm{C}$ and Welbull factor of 2.5. When there is a change in altitude to $1,000 \mathrm{~m}$ above sea level there is a decrease in density of $9 \%$ in average energy and the decrease in temperature to $15^{\circ} \mathrm{C}$ causes an increase of about $2 \%$ in the average energy density.

Table 3. Average wind speeds and densities by region

\begin{tabular}{|c||c|c|c|c|c|c|c|c|c|c|}
\hline & \multicolumn{2}{|c|}{ Forests } & \multicolumn{2}{c|}{ Open field } & \multicolumn{2}{c|}{ Coastal zone } & \multicolumn{2}{c|}{ Hills } & \multicolumn{2}{c|}{ Mountains } \\
\hline Class & $\begin{array}{c}\mathbf{V}_{\mathbf{m}} \\
(\mathbf{m} / \mathbf{s})\end{array}$ & $\begin{array}{c}\mathbf{E}_{\mathbf{m}} \\
\left(\mathbf{W} / \mathbf{m}^{2}\right)\end{array}$ & $\begin{array}{c}\mathbf{V}_{\mathbf{m}} \\
(\mathbf{m} / \mathbf{s})\end{array}$ & $\begin{array}{c}\mathbf{E}_{\mathbf{m}} \\
\left(\mathbf{W} / \mathbf{m}^{2}\right)\end{array}$ & $\begin{array}{c}\mathbf{V}_{\mathbf{m}} \\
(\mathbf{m} / \mathbf{s})\end{array}$ & $\begin{array}{c}\mathbf{E}_{\mathbf{m}} \\
\left(\mathbf{W} / \mathbf{m}^{2}\right)\end{array}$ & $\begin{array}{c}\mathbf{V}_{\mathbf{m}} \\
(\mathbf{m} / \mathbf{s})\end{array}$ & $\begin{array}{c}\mathbf{E}_{\mathbf{m}} \\
\left(\mathbf{W} / \mathbf{m}^{2}\right)\end{array}$ & $\begin{array}{c}\mathbf{V}_{\mathbf{m}} \\
(\mathbf{m} / \mathbf{s})\end{array}$ & $\begin{array}{c}\mathbf{E}_{\mathbf{m}} \\
\left(\mathbf{W} / \mathbf{m}^{2}\right)\end{array}$ \\
\hline 4 & $>6$ & $>200$ & $>7$ & $>300$ & $>8$ & $>480$ & $>9$ & $>700$ & $>11$ & $>1250$ \\
\hline 3 & $4,5-6$ & $80-200$ & $6-7$ & $200-300$ & $6,5-8$ & 250480 & $7,5-9$ & $380-700$ & $8,5-11$ & 6501250 \\
\hline 2 & $3-4,5$ & $25-80$ & $4,5-6$ & $80-200$ & $5-6,5$ & 100250 & $6-7,5$ & $200-380$ & $7-8,5$ & $300-650$ \\
\hline 1 & $<3$ & $<25$ & $<4,5$ & $<80$ & $<5$ & $<100$ & $<6$ & $<200$ & $<7$ & $<300$ \\
\hline
\end{tabular}

Source. Panorama of Wind energy in Brazil, (MME, 2007).

According to MME (2007), the resources presented in the legend of Table 3 above, refer to the average wind speed and average wind energy at a height of $50 \mathrm{~m}$ above the surface for 5 different topographic conditions defined as: coastal zone - beach areas, usually with a wide strip of sand where the wind predominantly affects the sea-land direction-, open field - flat pasture areas, plantations and/or low vegetation without many tall trees-, forests - areas of native vegetation with bushes and tall trees but of low density, type of terrain that causes more obstructions to the wind flow - hill — slightly wavy, relatively complex relief areas with little vegetation or grass-, mountain — complex relief areas with high mountains. 
The important elements that provided this enormous leverage of wind energy plants in Brazil are due to the fact that the winds reached high averages in many regions, with an annual average of around $8.5 \mathrm{~m} / \mathrm{s}$ in most of the states of the northeastern region and above $7.0 \mathrm{~m} / \mathrm{s}$ in Rio Grande do Sul. They also had constancy and regularity with great stability in its direction and perfect predominance in a certain angular direction, around $120^{\circ}$, with low variability along the days and months. Graph 1 , below, allows verifying the speed of the winds in two extreme regions: Northeast and South.

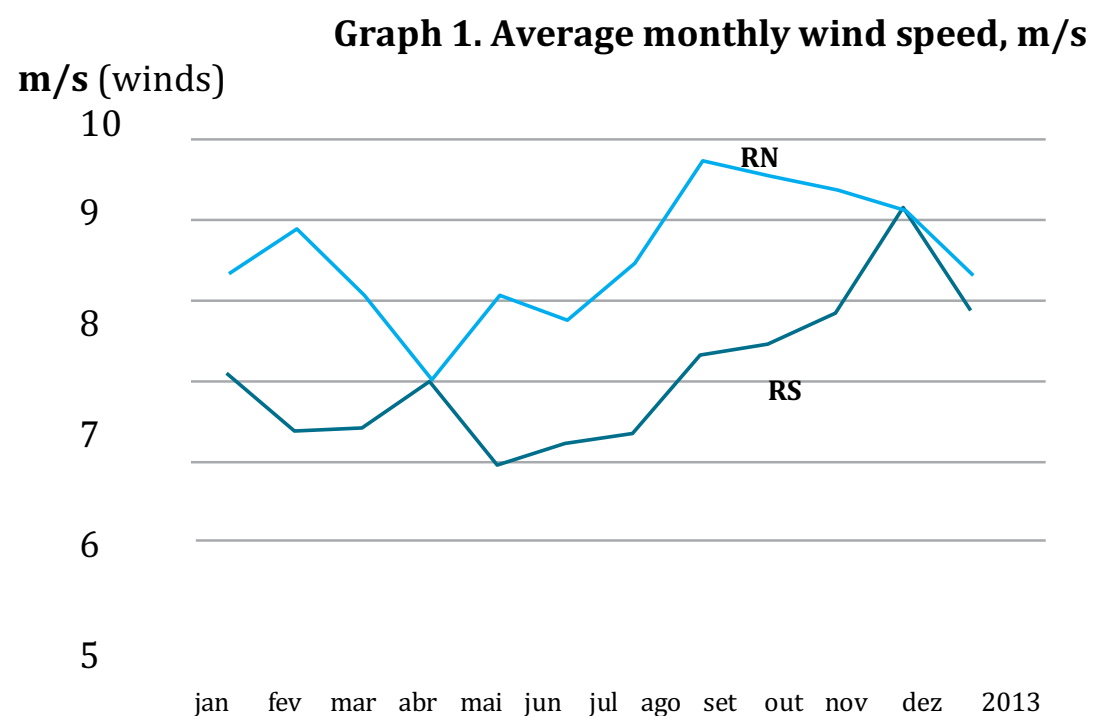

(RN) Rio Grande do Norte and (RS) Rio Grande do Sul (m/s), jan-dec 2013.

With the technological advance of wind turbine projects and manufacturing, the energy generation process has become harmless to the environment (noise and damage to birds) and its installation has simplified the environmental impact studies compared to other sources of energy and power generation. The licensing powers fix the delimitation of areas for its implantation. This element couples with the fact that high turbine production scales make the generation of electric energy by the wind energy system one of the technologies that has provided differentiated growth compared to the others, generating a high expansion in the electric power generation capacity.

In order to better understand the process of energy generation by the wind system, it is important to know how this is done: A wind turbine uses the kinetic energy of the wind that passes through the blades of the rotors causing them to spin and turns into electrical energy. Therefore, this electric energy is a function of the cube of the wind velocity and can be expressed in equation 1 , below:

where:

$$
\mathrm{P}(\text { watts })=\frac{1}{2} \delta \mathrm{A}_{\mathrm{r} v} v^{3} C p \eta
$$

$\mathbf{v}=$ wind speed,

$\delta=$ Air density in $\mathrm{kg} / \mathrm{m}^{3}$

$\mathbf{A}_{\mathrm{r}}=\pi \mathrm{D}^{2} / 4$; Where $\mathrm{D}$ is the diameter of the rotor,

$\mathrm{C} \rho=$ aerodynamic coefficient of rotor power tor,

$\eta=$ Efficiency of the generator / transmission set 
Evaluating this element, it is noticeable that the angular velocity of the rotor is inversely proportional to its diameter (D). Therefore, it is sought to make the rotation optimized in its design, to reduce and minimize the aerodynamic noise emission produced by the blades. A practical method for evaluating the nominal operating speed of a wind turbine is according to equation 2, below:

$$
\mathbf{r p m}=1150 / \mathrm{D}
$$

As the technology advances, larger turbine dimensions are made and rotation decreases (today the rotor diameters in the market range from 40 and $80 \mathrm{~m}$ ), which results in rotations of the order of 30rpm at $15 \mathrm{rpm}$, respectively. The blades with the current diameters provide low rotations, so the blades are easily visible by birds in flight, which avoid them.

The global potential for wind energy generation is estimated at 500,000 TW per year. However, due to the environmental restrictions it is considered valid, after the use of 55,000 TW, but still this net potential corresponds to four times the world consumption of electricity. In Brazil, the first computerized anemographs and special sensors for the evaluation of the national wind energy potential were installed in Ceará and Fernando de Noronha in the early 1990s. The results of these measurements enabled the determination of local wind potential and the installation of the first wind turbines in Brazil.

Gasch and Twele (2002) detail the evolution of wind energy technology from its use in windmills from $1700 \mathrm{BC}$ to modern aero-generators. Wind power is considered the most promising source of renewable energy for short-term electricity production, considering aspects of energy security, socio-environmental cost and economic viability (De Vries, 2009). The predominant energy matrixes make a marked use of fossil fuels or non-renewable minerals such as petroleum, coal, natural gas and uranium for the production of nuclear energy (Barbieri, 2007). This type of energy production and consumption pattern has generated a series of environmental effects throughout history, such as the emission of local pollutants and greenhouse gases, putting at risk the sustainability or long-term supply of the planet according to Goldemberg \& Lucon (2007). It should be emphasized that the pollutants emitted during these processes do not necessarily concentrate in a regional context and may reach other countries due to the interdependence relationship between ecosystems (Barbieri, 2007).

In this perspective, it is assumed that the excessive demand for energy generation reduces opportunities for development and damages the environment (Cohen, 2002). A concern arises for the planning of energy polices in a scenario in which there is a tendency of growth in world energy demand, in the improvement of the quality of life in the emerging countries (Martins, Guarnieri \& Pereira, 2008). There are currently more than 30,000 large-scale wind turbines in operation in the world, with installed capacity of $300 \mathrm{GW}$. In the framework of the International Climate Change Committee, the installation of $1,000 \mathrm{GW}$ by the year 2030 is planned. In Denmark, the contribution of wind energy is $12 \%$ of the total electricity produced. In Germany (Schleswig Holstein region), the wind contribution has already gone from $16 \%$ and the European Union aims to generate $10 \%$ of all electricity by 2025 .

China has expanded domestic investment in renewable energy generation and investing record highs in overseas renewable energy markets. According to the IEEFA report (2017), China's Global Renewables Expansion, China has contributed $\$ 32$ billion in foreign renewable energy projects in 2016 and intends to increase tenfold its renewable energy investments worldwide by 2020 . In Brazil, the use of wind resources has been carried out with more emphasis in the 
last ten years, and recently in several points in the national territory that indicate the existence of an enormous wind potential still unexplored.

\section{Economic and environmental factors}

The growing discussions in academic and professional environments on sustainability, $\mathrm{CO}^{2}$ emissions and climate change search for a way of conducting business and activities that influence the lives of human beings since the end of the last century (Van Marrewijk, 2003). All the issues surrounding this case have been influential around actions taken by the United Nations Conference on Human Development held in Stockholm in 1972, following a series of other events on environmental disasters, such as The Valdez case, the oil spill in Alaska, the nuclear accident at Chernobyl, as well as other social issues and economic prospects stemming from the oil crises of the 1970s, 1980s and 1990s (Van Bellen, 2004, Blackburn, 2007, CarriloHermosilla, Gonzalez \& Konnola, 2009).

The use of wind energy generation systems already has economic benefits for isolated use and for small power generation units, in regions where the geographical conditions are favorable for large volumes of wind and their constancy throughout the year. For this reason, new events stood out in this search for sustainable solutions, such as the United Nations Conference on Environment and Development in Rio de Janeiro in 1992 (Rio 92), which resulted in the creation of the Earth Charter with 27 principles. These principles should support the actions of the signatory countries and the formulation and signing of the Kyoto Protocol in 1997 and, subsequently, the Rio +10 conference in 2002 (Villa, 2009). The relationship between environmental sustainability, economic performance and competitiveness has been widely addressed for a long time, however, it continues with much discussion and lack of consensus among researchers and investors. It is possible to identify two ways of seeing this relationship in literature (Carrilo-Hermosilla, Gonzalez \& Konnola, 2009).

For a deeper analysis, some authors highlight the application of the Triple Bottom Line (TBL) concept by Elkington, (1987) and published officially in 2002. Following this discussion, Savitz and Weber (2006) add that the formation of a triple bottom line can be reflected in terms of the increase in the value of the company. This concept relates three pillars to analyze the sustainability phenomenon: economic, social and environmental perspective (Blackburn, 2007; Barking et al., 2010; Elkington, 2012). According to Junfeng, Pengfei \& Hu (2010), the dynamics of innovation, economic development and sustainability put wind power as one of the most competitive and promising renewable and sustainable energy sources that cause small problems that are avoidable and significantly lower than the effects from other sources of energy. Elkington (2012) discusses how to increase the use of sustainable energy in relation to the Triple Bottom Line, for a non-specific sequence to an isolated organization, but to a socioeconomic and environmental system. Still according to Elkington (2012, p. 275), to achieve exceptional performance along the three-pillar line, new types of economic, social and environmental partnerships are needed that are long-term and have a strong impact on preservation reduction of greenhouse gas emissions and reduce the greenhouse effect.

This can be obtained by means of gains around its human and environmental social capital, which can be measured through several elements, as can be seen in the simplification, shown in figure 1 , below. 
Figure 1. Aspects of measuring on the triple bottom line source.

\begin{tabular}{|l|l|l|}
\hline \multicolumn{1}{|c|}{$\begin{array}{c}\text { ECONOMIC } \\
\text { PILLAR }\end{array}$} & \multicolumn{1}{|c|}{ SOCIAL PILLAR } & $\begin{array}{c}\text { ENVIRONMENTAL } \\
\text { PILLAR }\end{array}$ \\
\hline Sales, revenue, & Employment Practices & Air quality \\
\hline Taxes paid & Impacts on the & Water quality \\
\hline Monetary flows & Human rights & Power usage \\
\hline Job creation & Cleaner production & Generation of solid \\
\hline
\end{tabular}

Adaptation of Savitz and Weber (2006)

Wind energy production has reached a level of global relevance in the energy generation process, which even during the global economic crisis of 2008 and 2009 continued to grow at an accelerated rate with rates of more than $40 \%$ in 2009 , according to Junfeng, Pengfei \& Hu (2010). For the authors, this growth is still strongly based on the installation of wind turbines on land, which accounts for more than 98\% of all installations by 2010; however, offshore energy production shows significant potential and currently represents only $1,5 \%$ of installed capacity. The expansion of the sector and the possibility of cheaper turbines, due to gains in scale, have contributed to new countries installing wind farms in their territories. In 2010, more than 100 countries had already installed wind farms (idem).

The wind power industry has been even more prominent with the marketing of clean energy production, by the free availability of its fuel, which is the wind. With this new scenario in 2010 , the sector obtained more than US $\$ 27$ billion in investments and employed more than 275,000 people (idem). This new reality that the sector is witnessing has contributed to the generation of incentives of diverse forms, stimulating investments and making the energy more economically interesting.

According to Moreira et al. (2013) from the Special Report on Sources of Renewable Energy, it will be necessary to triple the share of renewable energies in the world matrix until 2035. And, according to EPE (2016), despite the fact that equipment costs related to wind farms have fallen proportionally, the costs related to social and environmental issues for this sector have increased significantly, especially after the first auction for wind energy in 2009. This urgent need for alternatives to clean energy generation is due to the maintaining levels of carbon concentration in the atmosphere at a safe level.

Studies carried out by Freisleben \& Piscinatto, (2013) show the average annual velocity of the wind in Brazil and the country has a wind potential of around $143.5 \mathrm{GW}$. It is distributed as follows by Brazilian regions: Northeast region 52\%, Southeast region 21\%, South region 16\%, North region $9 \%$ and Central-West region $2 \%$.

According to Sandford (2012), the cost of electricity generated by a wind energy plant is directly proportional to the average wind speed of the site and also its constancy. This makes it possible to compare costs with energy from traditional sources, especially when the area has very high-speed averages. The central idea of cost reduction in relation to energy resources in Brazil is studying the possibility of building and installation of power plants, in addition to analyzing the best investment option.

As presented by Dalmaz et al. (2008), although the system presents several advantages, a wind system is subject to the whims of nature that sometimes, even with a great installed power, may not generate enough energy due to weak winds. Therefore, it is imperative to use specific 
methods for calculating a project and its cost in the design of energy production in a wind farm (Ferreira, Baron \& Fujita, 2016).

The advancement of technology has provided a dynamic adjustment to the blade dimensions, increasing for turbines. With this fact the rotation reduces (today the market rotor diameters range between 40 and $80 \mathrm{~m}$ ), resulting in low rotations ranging from 15 at 30rpm, respectively. The blades with the current diameters provide low rotations, so the blades are easily visible by birds in flight, which avoid them. Regarding the noise levels they produce in operation, wind turbines meet environmental requirements even when installed at distances of about $3 \mathrm{~m}$ and $300 \mathrm{~m}$ of residential areas. These factors contribute to the fact that the technology of electric power generation by wind generators presents the minimum environmental impact, among the sources of high generation of electric energy.

\section{METHOD}

Due to the complexity of decisions involving the energy market, affected by public policies allied to a need for new forms of interaction between organizations, the environment and society, research is relevant in providing learning and allowing better evaluation of future decisions of those involved in generating energy for sustainable growth. In order to organize the research in a logical process of reasoning and to satisfy the proposed objectives without being limited to an explanatory and descriptive research, this study adopted the method of comparative analysis aiming the construction of knowledge through real results, being able to be used for design future solutions

The methodology used in this work was based on the collection of information and data through extensive research and reviews of books, magazines and technical and scientific articles. Deductive and comparative research was also made, and files scanned on the Internet by specialized websites and national and International were reviewed. These methods allowed knowing, understanding and analyzing existing knowledge on the subject. It is an exploratory and descriptive research to obtain its objective and in relation to the ends. It is also bibliographical because it proposes the means of investigation and data analysis used throughout the process (Vergara, 2006).

The main bibliographic data sources were public in Brazil, with emphasis on the National Electric Energy Agency and the Ministry of Mines and Energy and on global organizations such as the Global Wind Energy Council and the Organization for Economic Cooperation and Development. These groups have a series of information on innovation and the trend of evolution of the sector in many countries. Therefore, the bibliographical data were taken from these to enable the researcher to have access to a broader coverage of the phenomenon. It was important to take the data from various groups because the study of an industry requires the collection of a series of information that could hardly be collected in a single work of the field (Gil, 2010).

The energy matrix is responsible for most of the greenhouse gas emissions, with priority being given to the use of clean energies such as solar, biomass and wind power. Hence, the research uses the economic comparison of the use of wind energy in small plants, as well as its reduction of $\mathrm{CO}^{2}$ emission to be able to align its costs and emissions.

When it comes to embedded energy approaches, they are molded into the fundamental concept of efficiency, and have direct relation to market need. Energy analysis includes all energy inputs that converge to the system, limiting to the local scale of analysis. It becomes a valuable 
tool to compare the inherent thermodynamic efficiency of the process under study, and to suggest possible technological improvements (ULGIATI et al., 2006).

Only the direct emissions (caused downstream) of the system under study will be accounted for. For estimating indirect emissions, the calculation procedure basically consists of using $\mathrm{CO}^{2}$ emission intensity factors $\left(\mathrm{kgCO}^{2} \mathrm{eq} / \mathrm{kg}\right)$ and multiplying them by the respective quantities of resources that enter the system studied.

The study made the comparative analysis between a Wind Energy Plant with capacity of 20 MW in the state of Ceará, a small hydroelectric plant (PCH) in the Paraíba do Sul River / SP of approximately $24 \mathrm{MW}$ and a thermoelectric plant with a capacity of $40 \mathrm{MW}$. The method used was appropriate for the analysis of the proposed system, given the reliability of the information provided by the cited sources. It allowed verifying the evolution of the sector and its current situation, projections and perspectives around issues involving sustainable energy generation and reduction of environmental impacts.

\section{RESULTS ANALYSIS}

The wind system is a technology that is currently associated with the use not only of mechanical and electrical theory, but also of computer science in its process of automation and control. The main components of a modern wind energy system for isolated applications or small power generation and distribution units are: rotor, transmission system, generator, system management command and lift tower.

The rotor, formed by three aerodynamic blades, is the component designed to capture the kinetic energy of the winds and convert it into mechanical energy in the axis that is the transmission system. The transmission system is the axis where the blades are attached, at the outer end, and the central part is coupled to the generator. The generator is the component that has the purpose of converting the mechanical energy of the axis, into electrical energy. The system management command is a microprocessor for the operational control of the system, both mechanical and electrical, in order to control the process of energy generation and the safety and quality of the product to be obtained. The support tower is the support of the rotor and generator set adapting to the height necessary for the best use of the wind.

The costs of an aero-generator (wind) system are strongly linked to the wind characteristics at the site of its installation, being directly proportional to its intensity. The higher the speed and the annual wind quantities are, the lower the cost will be. The irregularity of the terrain with its installation difficulties will also have an influence in the cost of the system. The wind system is becoming advantageous when constant winds are available, both economically and environmentally, translating into benefits for the quality of life and the very continuity of man's survival on our planet.

Wind power is an abundant source of renewable energy, clean and available everywhere. Currently, the wind turbine industry has been accumulating annual growth of more than $30 \%$ and moving about 15 billion dollars in sales per year. The generation of electricity through wind turbines is an alternative to a diverse range of demand levels. Small power plants can supply small localities far from the networks, contributing to the process of improving the quality of life. Regarding the large power plants, these have the potential to serve a significant portion of the National Interconnected System (SIN) with important environmental gains such as: contributing to the reduction of the emission of pollutants by the thermal plants in the 
atmosphere, reducing the need to build large reservoirs, and reducing the risk generated by hydrological seasonality.

Basically the cost of wind energy is determined by the following parameters: total cost of investment, operation and maintenance costs, percentage value of system operation, lifespan and depreciation and the average wind speed at the installation site. The data available in Germany, the most developed country in wind energy and the largest equipment manufacturer in the world, show us that the cost of manufacturing a wind generator plus the cost of the infrastructure is US \$ 1.20 per kW for sets from 450 to $600 \mathrm{~kW}$ capacity, on flat ground. These prices do not include the construction of roads nor the costs of the interconnection line or the reinforcement of existing lines.

The most important parameter for calculating the feasibility of an investment in wind energy generation is related to the knowledge of the local wind resources. Theoretically, the energy produced varies directly with the square of the average wind speed and its power varies with the speed cube. In practice, the power produced by an aero-generator varies with the wind speed according to its power curve, and the energy produced will be the integral of the power produced during the time it is in operation. Experimental data from Norway, Germany, Denmark and the UK over the past 8 years show that wind systems currently installed at sites with average wind speeds of $4.7 \mathrm{~m} / \mathrm{s}$ at a height of $30 \mathrm{~m}$ produce $800 \mathrm{kWh} / \mathrm{m} 2$; with winds at an average speed of $5 \mathrm{~m} / \mathrm{s}$ produce $1000 \mathrm{kWh} / \mathrm{m} 2$ and with an average speed of $9 \mathrm{~m} / \mathrm{s}$ produce annual energy values above $2000 \mathrm{kWh} / \mathrm{m} 2$.

The economic and natural viability for the development of the sector in line with other forms of renewable energy contributes to the avoidance of new investments in fossil energy sources, in addition to those already tendered or under construction (BRASIL, 2010). This shows the position of the Brazilian Government in the development and expansion of renewable energy technologies, and it is possible to verify, in the table below, the evolution of installed capacity for wind power production in the country compared to other Latin American countries included in the GWEC.

\section{Comparison of costs and emissions}

In order to economically compare the use of wind power in small power plants, as well as its reduction of $\mathrm{CO}^{2}$ emissions, and thus to be able to align its costs and emissions, the study analyzed a Wind Energy Plant with a capacity of $20 \mathrm{MW}$ in the state of Ceara, a small hydroelectric plant (PCH) in the Paraíba do Sul River/SP of approximately $24 \mathrm{MW}$ and a thermoelectric plant with a capacity of $40 \mathrm{MW}$.

\section{Wind Farm Cost}

In order to properly design a wind farm feasibility project and estimate the annual energy production to be generated, Leite et al. (2006) presents a computational model of probabilistic representation of this production, where the model also provides the calculation of performance indicators with a random combination of wind speed characteristics and other data that may represent the behavior of the wind energy plant by a Markov process. Leite et al. (2006) performed a test with real data of the main wind farms in regions of Brazil and the results reflected positively on the already installed parks. In Table 5 below, the data of the 20 MW Wind Energy Plant is shown. 
Table 5. Technical data of the 20MW plant

\begin{tabular}{|l|c|}
\hline \multicolumn{1}{|c|}{ INSTALLATION } & 20 MW, GENERATING 70,000 MWh / YEAR \\
\hline Equipment & 40 aero-generator with 500 $\mathrm{kW}$ each \\
\hline Local wind speed & Minimum $4.2 \mathrm{~m} / \mathrm{s}$ average $9.5 \mathrm{~m} / \mathrm{s}$ \\
\hline Local wind direction & $\begin{array}{c}96.5 \% \text { (between the minimum and } \\
\text { maximum) }\end{array}$ \\
\hline
\end{tabular}

Source: Brasil (2014).

Table 6 below presents financial data for the 20 MW Wind Energy Plant, with its energy generation costs per KWh.

Table 6. Financial data of the 20MW plant

\begin{tabular}{|c|c|}
\hline FINANCIAL & DATA \\
\hline Cost of air generators & US\$ 705,00 / KW \\
\hline Cost of infrastructure & US\$ $116,57 / \mathrm{KW}$ \\
\hline Cost of operation and maintenance (1) & US\$ 36,68 / KW \\
\hline Amortization of investment & 15 anos \\
\hline Operating system & $96,50 \%$ \\
\hline Average wind speed & $9,5 \mathrm{~m} / \mathrm{s}=2.000 \mathrm{KWh} / \mathrm{m} 2$ \\
\hline Average wind speed & $38,40 \%$ \\
\hline
\end{tabular}

Source: Brasil (2014)

Notes:

1. Estimating provided by EnerconWindpower (4.55\% pa) of the investment in the first 5 years;

2. Data provided by EnerconWindpower (2002);

3. Measurements of the COELCE, in the period of 2009, average wind speed, throughout the year guarantee this percentage of operation during the year;

4. The European Wind Energy Association (EWEA) study shows this average income in Europe.

5. Data from Michael Brower \& Co. - Andover, Massachusetts-USA. 1996.

For calculating the cost of energy generation in Dollar per KWh (US \$ / kWh), equation 3 below was used. And with the data presented in tables 1 and 2, the calculations of the cost of energy generated by the $20 \mathrm{MW}$ Wind Energy Plant were made.

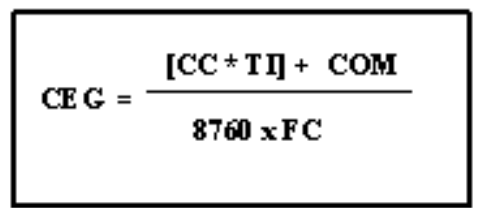

Fórmula l. Cálculo do custo da energia gerada(CEG) em K\$/kWh

where:

$\mathrm{CC}=$ Cost of Capital Invested (US \$ $/ \mathrm{KW}$ )

$\mathrm{TI}=$ Annual rate for investment (\% international)

$\mathrm{COM}=$ Cost of Operation and Maintenance (US \$ / KW)

$\mathrm{FC}=$ Capacity Factor in \%

Applying the data in equation 3 , the energy cost generated is US $\$ 0.0277 / \mathrm{KWh}$, according to the calculation below. 


$$
C E G=\frac{(705,00 \times 0,08)+36,68}{8.760 \times 0,384}=\frac{93,08}{3.364}=\text { US\$ } 0.0277 / \mathrm{KWh}
$$

\section{MW SHP Plant. cost}

According to data presented by Andrade and Bajay (1996), the results of the application of its pre-sizing model for SHP (Small Hydroelectric Power Plant), with 24 MW, in the Paraíba do Sul River / SP, see table 7, below:

Table 7. Technical data of the 24 MW SHP

\begin{tabular}{|l|l|}
\hline \multicolumn{1}{|c|}{ Installation } & 24 MW, generation with 12 turbines of 2000kW \\
\hline Speed and specific speed & $\mathrm{V}=300 \mathrm{~m} 3 / \mathrm{s}$ and $\mathrm{Ve}=336 \mathrm{rpm}$ \\
\hline Project cost and generated energy & US $\$ 38.575 .000,00$ and $105.120 \mathrm{MWh} /$ ano \\
\hline Cost of operation and maintenance & US $\$ 761.500,00=\mathrm{US} \$ 31,75$ \\
\hline Unit cost and generated energy & $\mathrm{US} \$ 1.607,15$ and US $\$ 0.0366 / \mathrm{KWh}$ \\
\hline
\end{tabular}

Source: ANEEL, 2015

Also, for the elaboration of cost calculations of KWh dollars (US\$ / kWh) of the Paraíba do Sul Power Plant, equation 3 was used. And with the data presented in table 5, the calculations were prepared for the cost of energy generated in this small hydroelectric power station.

Therefore, the cost of generating power at the $24 \mathrm{MW}$ plant is US $\$ 0.0366$ / $\mathrm{kWh}$.

\section{Thermal Plant. cost}

In Table 8, below, technical data of a 40MW thermal plant is presented.

$$
\mathrm{CEG}=\frac{(1.607 .15 \times 0,08)+31.75}{8.760 \times 0,5}=\frac{160.32}{4.380}=\mathrm{US} \$ 0.0366 / \mathrm{kWh}
$$

Therefore, the cost of generating power at the $24 \mathrm{MW}$ plant is US $\$ 0.0366 / \mathrm{kWh}$.

\section{Thermal Plant. cost}

In Table 8, below, technical data of a 40MW thermal plant is presented.

Table 8. Technical data of a 40MW thermal plant

\begin{tabular}{|l|l|}
\hline \multicolumn{1}{|c|}{ Installation } & \multicolumn{1}{c|}{ 40 MW, Generated with oil burning } \\
\hline Project cost and generated energy & US $\$ 142.850 .000,00$ and $300.000 \mathrm{MWh} /$ year \\
\hline Cost of operation and maintenance & US $\$ 2.100 .000,00=$ US $\$ 51.40$ \\
\hline Unit cost and generated energy & US $\$ 3.575,00$ e US $\$ 0.1027 / \mathrm{kWh}$ \\
\hline
\end{tabular}

Source: Brazil, 10-year energy expansion plan, MME / EPE, 2010.

$$
\mathrm{CEG}=\frac{(3.575,00 \times 0,08)+51,40}{8.760 \times 0,375}=\frac{337,40}{3.285}=\mathrm{US} \$ 0.1027 / \mathrm{KWh}
$$

Calculating the cost of the KWh (US \$ / kWh) energy in dollars, the equation 3 was also used. And with the data presented in table 5 the calculations were made for the cost of energy generated in this small thermal energy generator. 


\section{$\mathrm{CO}^{2}$ emissions}

The $\mathrm{CO}^{2}$ Factor; to know how to calculate the reduction of emissions, it is necessary first to know what is the $\mathrm{CO}^{2}$ factor of the Brazilian energy matrix. The $\mathrm{CO}^{2}$ factor represents the amount of carbon dioxide emitted for the production of $1 \mathrm{kWh}$, which is measured in $\mathrm{kgCO}^{2} / \mathrm{kWh}$. The more fossil fuels are burned to generate energy for a given country, the greater the amount of $\mathrm{CO}^{2}$ produced, increasing its $\mathrm{CO}^{2}$ factor. The Ministry of Mines and Energy indicates that, in 2016, the average value of the $\mathrm{CO}^{2}$ factor in Brazil was $0.08 \mathrm{tCO}^{2} / \mathrm{MWh}$. As an example, it can be indicated that every 500MWh produced, an average of 40 tons of carbon dioxide was generated.

Due to the segmentation of the Brazilian energy matrix, composed mainly of hydroelectric plants, the national $\mathrm{CO}^{2}$ factor is lower than that of other countries dependent on a larger number of thermoelectric plants. However, as already indicated, periods of long droughts imply the need to activate thermoelectric plants that increase the emission of pollutants, besides of course implying in rate increases.

For $\mathrm{CO}^{2}$ emissions is important to compare the amount of gas emitted (measured in tons of carbon equivalents $(\mathrm{tC})$ ), on the power generated per hour $(\mathrm{MWh})$, and to compare $\mathrm{CO}^{2}$ emissions in thermoelectric and hydroelectric plants. The carbon equivalent is the unit that considers both carbon dioxide $\left(\mathrm{CO}^{2}\right)$ and methane ( $\left.\mathrm{CH} 4\right)$. As the thermal potential of $\mathrm{CH} 4$ is 25 times greater than that of $\mathrm{CO}^{2}$, it is necessary to multiply the measured value of $\mathrm{CH} 4$ by 20 to express it in carbon. In Table 9, bellow we can verify the values of $\mathrm{CO}^{2}$ emissions.

Table 9. Direct and fugitive emissions of $\mathrm{CO}^{2}$ in electricity generation $\left(\mathrm{kgCO}^{2} / \mathrm{MWh}^{2}\right.$

\begin{tabular}{|l|c|c|c|}
\hline Emission & Diesel & Hydraulics & Wind \\
\hline Generation & 80,0 & 41,9 & 2,4 \\
\hline Leaks & 9,8 & 11,7 & 0 \\
\hline Total & 89,8 & 43,6 & 2,4 \\
\hline
\end{tabular}

Source: Santos, (2008)

In Table 9 above, are indicated in generation. Fugitive emissions so-called because they result from the escape of greenhouse gases (mainly methane) at different stages of the generation cycle are also indicated.

\section{Data comparison}

Comparing the three projects, we can see the large cost difference of the energy generated by the wind system confronted with a SHP and a thermal plant in this reserch. The differences shown in Table 10, below, not only demonstrate the cost aspect, but also the emission of greenhouse gases that each one of the energy generating sources plays to the environment.

Table 9. Comparison of greenhouse gas emissions $(\mathrm{Kg} / \mathrm{CO} / \mathrm{KWh})$ and cost per $\mathrm{KWh}$

\begin{tabular}{|l|c|c|c|c|c|c|}
\hline $\begin{array}{c}\text { POWER } \\
\text { PLANT }\end{array}$ & $\begin{array}{c}\text { MW } \\
\text { POWER }\end{array}$ & $\begin{array}{c}\text { CAPACITY } \\
\text { MW/YEAR }\end{array}$ & $\begin{array}{c}\text { CO }^{2} \\
\text { EMISSION * 1 }^{2}\end{array}$ & $\begin{array}{c}\text { CH4 } \\
\text { EMISSION * 2 }\end{array}$ & $\begin{array}{c}\text { ISSUANCE } \\
\mathbf{Y}^{* 3}\end{array}$ & $\begin{array}{c}\text { COSTUS\$ } \\
\text { / kWh }\end{array}$ \\
\hline Eolic & 10 & 35.000 & 0,0024 & 0 & 0 & 0,0277 \\
\hline Hydraulics & 24 & 105.200 & 0,0436 & 0,00019 & 0,00018 & 0,0366 \\
\hline Thermal & 40 & 300.000 & 0,0898 & 0,00048 & 0,00021 & 0,1027 \\
\hline
\end{tabular}

\section{Source: Research Data}

Observations:

*1 kg (CO2) / MJ Santos, (2008); Santos, et all (2008)

*2 CH4 (Methane) Santos, et all (2008)

*3 Y (Other greenhouse gases effect) Santos, et all (2008) 
As a result of the evaluation and comparison of the means of energy generation, it can be seen that in addition to the benefits of reducing emissions of pollutants, especially $\mathrm{CO}^{2}$ and its economic viability, it was also possible to verify that the wind industries in the country, according to information of the official Global Energy Council website, (2015) generate more than 25,000 direct jobs in the industry. Another important factor to highlight is the social impact that the exploitation of the activity can have for the country, contributing to the generation of new jobs, promoting a greater social inclusion in the country. This perspective is also supported by Salles (2009), in view of the author's argument that wind farms in rural areas generate direct and indirect jobs, as well as allowing areas between turbines to be used for animal husbandry.

A negative impact of wind energy plants is the possibility of electromagnetic interference, which can cause disturbances in radio and television data and communication systems (Taylor, 2001). According to the author, these interferences vary widely depending on the location of the plant and its technical specifications, particularly the material used in the manufacture of the blades. Also, interference in bird routes should be duly considered in studies and reports of environmental impacts.

The noise emitted by the air-generators decreases by $50 \mathrm{~dB}$ near the air-generators to $35 \mathrm{~dB}$ at a distance of $450 \mathrm{~m}$ from the towers. The physiological effects on the auditory system only begin to act from $65 \mathrm{db}$. However, values higher than $40 \mathrm{~dB}$ can cause psychic effects on man and the recommended noise level is less than $40 \mathrm{~dB}$. The $40 \mathrm{~dB}$ noise corresponds to a distance of $200 \mathrm{~m}$ aerators, this being the distance between aero-generators and respected dwellings in Europe.

\section{FINAL CONSIDERATIONS}

Analysis of the development of renewable sources shows that they are fundamental for sustainable growth not only for environmental reasons, but also for economic reasons (import dependence, impact on trade balance, supply risk, scarcity of non-renewable resources, etc.), social reasons (generation of jobs, increase of income, access to energy) and technological reasons (development of industrial park and clean technology).

In order to meet the great demand of energy that our planet will require in the next decades, it is necessary to develop and make appropriate new ecologically correct resources of generation of energy, that is, that do not emit greenhouse gases that impact negatively in our ecosystem and generate harmful climate change. Around the year 2030, for example, the energy that will be consumed around the world will have grown by $50 \%$ of the current volume, mainly due to the increase of energy consumption in the emerging countries of Latin America and Asia. It is known, however, that fossil fuels represent values of reserves that being consumed in the current quantities will not be able to meet their demand in the near future.

Taking the above into account, it was possible to verify that the environmental benefits that the innovations in the Brazilian wind sector has been passing are related to the exploration of new sources of raw material for the production of energy, contributing to the reduction of pollutant gases and reduction of dependence of fossil fuels. Additionally, complementary forms for hydropower, in view of the increased potential for wind power production in periods of drought have been made. Accordingly, it was possible to verify that the pillars of sustainability (economic, social and environmental) can be seen along all issues involving the implementation of new wind farms.

The results show the following advantages of wind energy plants: 
- Comparative cost: 25\% lower than hydroelectric and 63\% lower than thermal;

- Emission of greenhouse gases: insignificant values against very high values of other sources of energy;

- Very low environmental impact comparing with the others energy generation.

The limitation of this study refers to the method, since the method was not mathematically validated and, therefore, could not represent does a consistent sample. However, this model is not final and definitive, remaining open to improvements. Even if the research was limited to the available data for evaluation, the creation of the model brought a facility in the import of data referring to other plants.

Future research is recommended, involving larger capacity wind farms and all the elements that can generate economic, environmental and social impacts that allow a systematic comparison with other countries, increasing the knowledge about its influence and technological development.

\section{References}

ABEÉOLICA, (2014). Dados, Nosso Setor, São Paulo, 2014. Disponível em <http:/ www.portalabeeolica.org.br/ index.php/dados.html> accessed in 14/07/2015.

Alves, J. J. A. (2010). Análise regional da energia eólica no Brasil. Revista Brasileira de Gestão e Desenvolvimento Regional - G\&DR. 6(1):165-188.

Andrade, M.T.O. \& Bajay, S.V. (1996). Uso sustentável de energia, Unicamp.

ANEEL - Agência Nacional de Energia Elétrica. (2015). Energia Eólica. Disponível em <http://www.aneel.gov.br/aplicacoes/atlas/energia_eolica/6_2.htm>. Accessed in: 12/06/2015.

ANEEL. (2017). Brasil registra recorde anual de nova capacidade instalada de geração em 2016. 2017. Assessoria de Imprensa. (2017). Disponível em: <https://goo.gl/VzF1ZV>. Accessed in 09/02/2017.

Bajay, S. V. \& Walter, A. C. S. (2000). Geração descentralizada de energia elétrica. In: Simpósio brasileiro sobre cogeração de energia na Indústria,1. Anais. Campinas: Unicamp. p.19-42.

BarbierI, J.C., Vasconcelos, I.F.G., Andreazzi, T. \& Vasconcelos, F.C. (2010). Inovação e sustentabilidade: novos modelos e proposições. Revista de Administração de Empresas, 50(2):146-154.

Blackburn, W. R. (2007). The sustainability handbook: the complete management guide to achieving social, economic and environmental responsibility. Washington: ELI Press.

Boyle,g. (1996). Renewable energy: power for a sustainable future.Oxford UniversityPress, Oxford.

BRASIL, 2014. Resolução n. 462, de 24 de julho de 2014. Disponível em:

<http://www.mma.gov.br/port/conama/legiabre.cfm?codlegi=703>. Accessed in 25/2/2016.

Britannica, (2001). Encyclopaedia. CD Deluxe.

British Petroleum-BP. (2016). Energy Outlook: Outlook to 2035. 2016. Disponível em: < https://www.bp.com/content/dam/bp/pdf/energy-economics/energy-outlook-2016/bp-energy-outlook-2016.pdf>. Accessed in: 25/01/2017.

Cahn, M. A. (1995). Environmental Deceptions. The tension between Liberalism and Environmental Policymaking in the United States. State University of New York Press. Albany. c.8, p.121-140.

Carrillo-Hermosilla, J.; Gonzalez, P. D. R. \& Konnola, T. (2009). Eco-innovation: when sustainability and competitiveness shake hands. New York: Palgrave Macmillan.

De Vries, B.J.M.; Van Vuuren, D.P. \& Hoogwijk, M.M. (2007). Energy Policy.35:2590.

Dalmaz, A.; Passos, J. C. \& Colle, S. (2008). Energia eólica para geração de eletricidade e a importância da previsão. Revista ABCM - Engenharia, v.XIII, n.1.

Dolan, S. L. \& Heath, G. A. (2012). Life Cycle Greenhouse Gas Emissions of Utility-Scale Wind Power. Journal of Industrial Ecology, 16, S136-S154. 
Dutra, R. M \& Guedes, V.G. (2012). Evaluation of the new Brazilian regulation concerning low Voltage Distribution Network: An Opportunity For Small Wind Turbines. DEWEK 2012. Bremen Germany.

Eletrobras. (2014). Inventário de emissões de gases de efeito estufa. Disponível em:<http://www.eletrobras.com/elb/main.asp?Team=\%7B42C746D5-89A0-4D98-9246-9AEA402BE8F6\%7D >. Accessed 22/06/2015.

Elkington, J. (1997). Cannibals with forks: The triple bottom line of $21^{\text {st }}$ century business Release: Publisher: Capstone Publishing Ltd, Oxford.

Elkington, J. (2012). Sustentabilidade: canibais com garfo e faca. Edição histórica de 12 anos. São Paulo: M. Books.

Edenhofer, O., Pichs, R., Madruga, Sokona, Y., Seyboth, K., Matschoss, P., Kadner, S., Zwickel, T., Eickemeier, P., Hansen, G., Schlömer, S. \& Von Stechow, C.E., (2011). IPCC Special Report on Renewable Energy Sources and Climate Change Mitigation. Cambridge University Press, Cambridge, United Kingdom and New York, USA.

EWF-Brasil. (2015). Desafios e Oportunidades para energia eólica no Brasil: recomendações para políticas públicas. Brasilia. WEF-Brasil.

EWEA-(1995). The European Wind Energy Association and Corporate Group on the European Commission Energy. Green Paper. May.

Ferreira, D. H. L.; Baron, C. \& Fujita, L. H. (2016). An application of full cost assessment in the energy sector. Independent Journal of Management \& Production (IJM\&P). 7(3):903-913.

Foden, W., Midgley, G.F., Hughes, G., Bond, W.J., Thuiller, W., Hoffman, M.T, Kaleme, P., Underhill, L.G., Rebelo, A., \& Hannah, L. (2007). A changing climate is eroding the geographical range of the Namib Desert tree Aloe through population declines and dispersal lags. Diversity and Distributions 13:645-653.

Franco, A.C.; Bustamante, M.M.; Caldas, L.S.; Goldstein, G.; Meinzer, F.C.; Kozovits, A.R.; Rundel, P. \& CoradiN, V.T.R. (2005). Leaf functional traits of Neotropical savanna trees in relation to seasonal water deficit. Trees Structure and Function. 19(3):326-335.

Freisleben, A. P. \& Piscinatto, A. C. (2013). O Papel da Indústria Nacional de Equipamentos dara Energia Eólica na Sustentabilidade. Revista Eletrônica Geoaraguaia. Barra do Garças-MT. Edição Especial. p.77-95. Setembro.

Gasch, R. \& Twele, J. (2002). Wind Power Plants: Fundamentals, Design, Construction and Operation. Solarpraxis AG, Alemanha.

Gil, A. C. (2010). Como Elaborar Projetos de Pesquisa. São Paulo: Atlas, 2010.

Global Wind Energy Council, (2015). Global Wind Market Report on the state of the global wind industry on 25 April 2015.

Grubb; M. \& Meyer, N.I. (1993). Wind energy: resources, systems, and regional strategies, chapter 4:157-212, in Renewable Energy: Sources for Fuels and Electricity, Thomas B. Johansson, Henry Kelly, Amulya K.N. Reddy, and Robert H. Williams, Island Press, Washington, DC.

IEEFA, (2017). Institut for Energy Economics and Financial Analysis. China's Global Renewables Expansion: How the World's Second-Biggest Economy Is Positioned to Lead the World in Clean-Power Investiment.

2017.Disponível em: <https://goo.gl/7foyqd>. Accessed in:10/01/2017.

IPCC (2007). - Intergovernmental Panel on Climates Change. Fourth Assessment Report.

EPE. (2016). Ministério de Minas e Energia. Energia Renovável: Hidráulica, biomassa, eólica, solar, oceânica. Maio 2016. Mauricio Tiomno Tolmasquim. Disponível em: <https://goo.gl/NZKNHhaccessed in: 02/10/2016.

Junfeng, L., Pengfei, S. \& Hu, G. (2010). China wind power outlook 2010. Bélgica: GWEC.

Kabir, M. R., Rooke, B., Dassanayake, B.A. \& Fleck, B. A. (2012). Comparative life cycle energy, emission and economic analyses nameplate win power generation.Review Sustein Energy Rev. 37:133-141

Leite, A. P.; Borges, C. L. T. \& Falcao, D. M. (2006). Modelagem de usinas eólicas para estudos de confiabilidade. Revista Controle \& Automação, 17(2).

Lovejoy, T.E. \& Hannah, L.J. (2005). Climate change and biodiversity. London. Yale Press.

McCarty, J. A. \& L.J. Shrum (2001) The Influence of Individualism, Collectivism, and Locus of Control on Environmental Beliefs and Behavior. Journal of Public Policy \& Marketing: Spring 2001, 20(1):93-104.

Maia, T. A. \& Andrade, C. F. (2017). Análise da Inserção de Energia Eólica na Matriz Elétrica Brasileira. Trabalho de Conclusão de Curso. Universidade Federal do Ceará. 
Martins, F.R., Guarnieri, R.A. \& Pereira, E.B. (2008). 0 aproveitamento da energia eólica. Revista Brasileira de Ensino de Fisica. 30(1):1304.

Mason, I.G, Page, S.C \& Williamson, A.G. (2010). 100\% renewable electricity generation system for New Zealand utilising hydro, wind, geothermal and biomass resources. Energy Policy, 38:3973-3984.

MCT-Ministério da Ciência Tecnologia. (2008). Relatório desenvolvimento social econômico sustentável.

MEA. (2005). Millennium Ecosystem Assessment.

MME - Ministry of Mining and Energy, (2007). Brazil; “National Energy Balance” (the latest data from 2006, available at www.mme.gov.br). Available at www.mme.gov.br.

Monzoni, C. M. (2009). Direct complaints in (Italian) calls to the ambulance: The use of negatively framed questions. Journal of Pragmatics. 41:2465-2478.

Moreira, R. N, Vidal, F.A.B. \& Viana, A. F. (2013). Energia eólica no quintal da nossa casa?! Percepção ambiental dos impactos socioambientais na instalação e operação de uma usina na comunidade de sítio do Cumbe em Aracati- CE. GeAS - Revista de Gestão Ambiental e Sustentabilidade. 2(39).

NAE. (2008). Centro de Estudos Integrado sobre Meio Ambiente. Núcleo de Estudos Estratégicos da Presidência da República.

Forster, P. et al. (2007). Changes in atmospheric constituents and radiative forcing. In: solomon, S. \& QIN, D.; Manning, M.; Chen, Z.; Marquis, M.; Averyt, K. B.; Tignor, M.; Miller, H. L. Climate Change 2007: The Physical Science Basis. Contribution of Working Group to the Fourth Assessment Report of the Intergovernmental Panel on Climate Change. Cambridge: Cambridge University Press. p.129-234.

Parmesan, C. (2006). Ecological and Evolutionary Responses to Recent Climate Change. Annual Review of Ecology, Evolution, and Systematics. 37:637-669.

Ribeiro, S., Moros, M., Ellegaard, M. \& Kuijpers, A. (2012). Climate variability in WestGreenland during the past 1500 years: evidence from a high-resolution marine palynological record from Disko Bay. Boreas, 41:68-83.

Salles, M. J. (2009). Política nacional de saneamento: percorrendo caminhos em busca da universalização. $185 f$. Tese (Doutorado em Ciências na área de Saúde Pública). Escola Nacional de Saúde Pública Sergio Rio de Janeiro.

Santos, M.A. (2000). Inventário de emissões de gases de efeito estufa derivadas de hidrelétricas. Tese de doutorado. Universidade Federal do Rio de Janeiro, Rio de Janeiro, RJ, Brasil. 148p.

<http://www.ppe.ufrj.br/ppe/production/tesis/masantos.pdf>. accessed in 05/06/2015.

Santos, M.A.; Rosa, L.P.; Matvienko, B.; Santos, E.O.; D’almeida R.,Rocha, C.H.E.; Sikar, E.; Silva, M.B. \& Junior, A.M.P.B. (2008). Emissões de gases de efeito estufa por reservatórios de hidrelétricas. Oecologia Brasiliensis, 12:116-129.

Savitz, A. W. \& Weber, K. (2006). The triple bottom line: how today's best-run companies are achieving economic, social and environmental success and how you can too. São Francisco: Jossey-Bass.

Shindell, D. T.; Faluvegi, G.; Koch, D. M.; Schmidt, G. A.; Unger, N. \& Bauer, S. E. (2009). Improved attribution of climate forcing to emissions. Science, 326:716-718.

Silva, R. V. (2013). Estudo da sensibilidade da estimativa de vento no modelo WAsPr relativa à rugosidade superficial. 2013, 112p. Dissertação (Mestrado em Engenharia Mecânica) - Universidade Federal de Pernambuco. Recife.

Taylor, J.T. (2001). Economic and market potential of small innovative reactors, paper presented at the Workshop on New Energy Technologies: a Policy Framework for Micro-Nuclear Technology. Houston, TX, 19-20 March.

Thomson, R. C. \& Harrison, G. P. (2015). Life cycle costs and carbon emissions of onshore wind power: Main report. Edinburgh, Scotland: ClimateXChange.

Van Bellen, \& H. M. (2004). Indicadores de sustentabilidade: um levantamento dos principais sistemas de avaliação. Cad. EBAPE.BR, 2(1):14.

Van Marrewijk, M. (2003). Concepts and definitions of CSR and corporate sustainability: between agency and communion. Journal of Business Ethics, 44:95-105.

Vergara, S. C. (2006). Métodos de pesquisa em administração. 2. ed. São Paulo: Atlas.

Villa, A. O. M. (2009). Gestão da inovação na indústria brasileira de higiene pessoal, perfumaria e cosméticos: uma análise sob a perspectiva do desenvolvimento sustentável. 2009. 169 p. Tese (Doutorado em Política 
Científica e Tecnológica) - Pós-Graduação em Política Científica e Tecnológica, Universidade Estadual de Campinas, Campinas.

Walther, G.-R.; Berger S. \& Sykes M. T. (2005). An ecological 'footprint' of climate change. Proc. R. Soc. B 272, 1427-1432

WEA. (1999). Wind Energy Association. Global wind energy market report. Washington, DC, 1999. <http://www.awea.org> accessed in 29/05/2015.

Whitaker, M., Heath, G. A., O'donoughue, P. \& Vorum, M. (2012). Life Cycle Greenhouse Gas Emissions of Coal-Fired Electricity Generation. Journal of Industrial Ecology, 16, S53-S72.

Windpower. (2002). Monthly, October, p.21-49. RDA. 